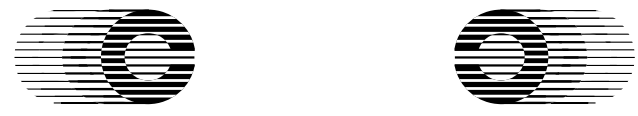

1本の高分子鎖の構造と 光機能のイメージング

東北大学大学院工学研究科金属工学専攻 篠原健一

1.はじめに

多くの合成高分子は非常に優れた物性を有する有用 な物質であり，すでに我々人類にとって不可欠な材料で ある. ところが, 合成高分子は一般に, 光の構造か動的で ある (やわらかい) うえに多樣であるため, 分子レベル の構造と機能の相関関係を明確に議論することか灘し

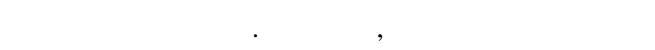
構造が,いかなる機能を発揮しているのか?」という問 いに対して, これまで直接分子レベルで明確に答えるこ とが難しかった. 弚こで私は, もしポリマー1分子の構 造と機能を直接観測することができれば, 仮定や推測を 最小限に抑えることが可能になり, 最も明確にポリマー の構造と機能との相関関係を議論できるものと考えた.

一方, 生体高分子であるタンパク質は, 生命機能の発 現に重要な役割を担っている. タンパク質が有する卓 越した柔軟な機能は, タンパク質が形成しているしな やかな高次構造によって本質的に発現していると考え られている. 帯こで, 合成高分子にタンパク質のような 高次構造を形成させること,すなわち, ポリマーとタン パク質の分子融合ができれば, 卓越した特異的な機能 を有し,かつ機能材料として実用可能な耐久性を併せ もつ高分子を創製できるのではないかと考えた. この 研究は,「物質と生命のかけはし」を狙ったものであり， 一連の基礎研究の成果のなかから新しい概念が創出さ れるものと期待している.

本研究では, 数ある合成高分子のなかでも特に, 発光 機能や導電機能を備える新しいタイプの高分子材料と して, エレクトロルミネッセンス (電界発光：EL) 素 子やポリマー電池などに実用化され, 次世代の機能材料 としてますます期待されている機能性高分子である, $\pi$
共役ポリマー (以下, 単にポリマーとする) の1 分子構 造と機能のダイナミクスに着目した. 本稿の前半では, ポリマー1分子の主鎖のヘリックスに基づく高次構造 の直接観測について概説し ${ }^{1)}$, 後半では, 新たな顕微鏡2) を製作して行った, 蛍光性ポリマー1分子の動的発光機 能の直接観測について述べる ${ }^{3)-5)}$.

2 . 走査型トンネル顕微鏡 (STM ) によるポリマー 1分子のへリックス構造のイメージング

本研究では, 分子設計のうえ, 新規に合成したポリマ -1 分子の STM 観測を実施し, ポリマーの右巻きのへ リックスと, この1次構造から4次構造までのキラル (不斉) な階層構造を直接捉え, 合成高分子における 4 次構造の実在を証明, さらに光のへリックスのピッチ などの直接計測をも達成した1).

STM 観測に用いたポリマー[(-)-ポリ(MtOCAPA), 図1a] は, 置換フェニルアセチレンポリマーの一種で ある.これは, ( - )-L-メントール (ハッカの主成分) を 出発物質としてモノマーを合成し, これをロジウム触 媒によって重合させることで得られた. このポリマー は $1 \times 10^{6}$ の重量平均分子量を有する高分子量体であ り, 主鎖の立体規則性を示すシス％は90を超え, 高度に シス型に制御された主鎖をもつことがわかった. ポリ マーの1次構造はプロトン核磁気共鳴 ('H NMR) スペ クトルで確認した.

図1bに示したポリマーの円偏光二色性 (CD) およ び紫外可視吸光 (UV-VIS.) スペクトルを見るとおり,

(a)

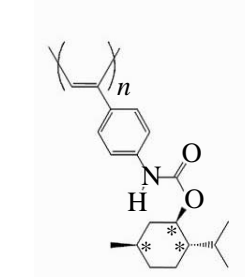

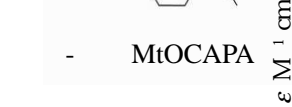

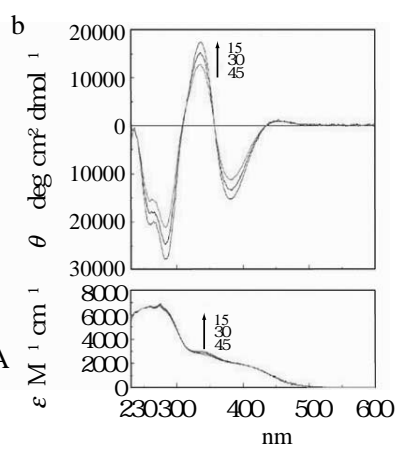

図1 (a) ( - )-ポリ (MtOCAPA) の化学構造, (b) ポリマーのテト ラヒドロフラン溶液の円偏光二色性スペクトル (上) と紫外 可視吸光スペクトル (下) (カラー画像はオンラインジャーナ ルをこ覧ください. 図2, 図4も)

\title{
Single Molecule Imaging of Structure and Function in a $\pi$-Conjugated Polymer
}

Ken-ichi SHINOHARA

Department of Metallurgy, Tohoku University 


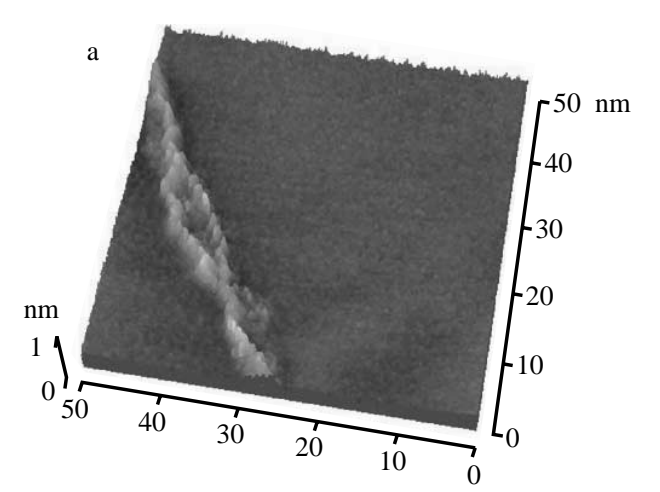

(b)

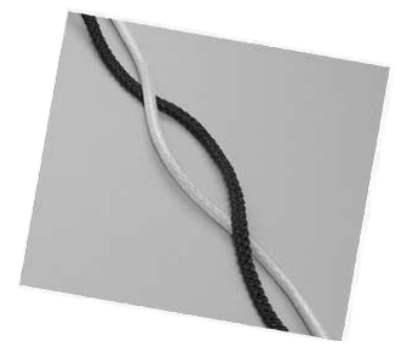

図2 (a) ( - )-ポリ(MtOCAPA) のキラル4次構造の走査トンネル顕 微鏡像 (グラファイト基板上大気中室温下), (b)ひもモデル

キラリティーは側鎖のみならず, 主鎖にも存在するこ とがわかった. このことは, 側鎖の光学活性な置換基の 存在によって, 重合反応の際に, 主鎖に不斉か誘起され たことを示している.つまり, このCDスペクトルは, ポ リマー主鎖が片方向巻きのヘリックスとしての2次構 造を形成していることを示している. また, このCDシ グナルの強度は試料温度が低下するにしたがって増大 する, 可逆的な現象であつたことから,このへリックス は柔軟であることが示唆された.

図2aにグラファイト (HOPG) 基板上, 室温下, 大気 中で捉えたポリマーの低電流STMの像を示す. バイア ス電圧 $\left(V_{\mathrm{s}}\right)$ は $20.0 \mathrm{mV}$, トンネル電流值 $\left(I_{\mathrm{t}}\right)$ を 30.5 $\mathrm{pA}$ に保ち, 探針を $3.05 \mathrm{~Hz}$ で走査した. ポリマー鎖 2 本 が絡み合っているようすを観察でき,さらに右巻きの ヘリックスが確認できた. このへリックスを巻いてい る鎖 1 本の幅は $0.9 \mathrm{~nm}$ であり, このサイズは分子力場 (MM) 計算で最適化して得られた重合体 (20量体) の ポリフェニルアセチレンの主鎖骨格の幅に一致した. このことから, 得られたSTM像はポリマー主鎖の $\pi$ 電 子軌道であることが支持され, さらにCDスペクトルで 確認された 2 次構造らせんがさらに右巻きらせんを巻 いたスーパーヘリックスの3 次構造であることが明ら かになった. 光して, 光の断面の解析の結果, このスーパ 一ヘリックスのピッチは $2 \mathrm{~nm}$ であることがわかった.
これは分子モデルの幅 $(2.4 \mathrm{~nm})$ に一致することから， 最密構造のスーパーヘリックスであることを示してい る. また, スーパーヘリックスの幅は $2 \mathrm{~nm}$ であること, そして $10 \mathrm{~nm}$ 以上の範囲にわたって厳密に右巻きスー パーヘリックスの3 次構造か制御されていることまで もか明らかになった.

さらに, 高分子鎖が 2 本, 図 $2 b$ に示すモデルのように, 右巻きに互いに絡み合って 2 重らせん構造を形成して いるようすか観測できた. これによって, さらに上のキ ラルな階層構造である, 4 次構造の実在を明らかにする ことができた. またこれは, 探針で連続して走査するた びに形状を変化させることができるほど, 柔らかい $\pi$ 電 子共役構造体であることも確認された.

本研究により, 合成高分子の 1 次から 4 次構造までの キラルな階層構造の存在が明らかにされた. この特異 的な $\pi$ 電子系構造の新規な電子的および光機能の発現 か期待される.

\section{3 . 全反射型蛍光顕微鏡 (TIRFM) による} ポリマー1分子の光機能のイメージング

本研究では, $\pi$ 共役系主鎖 1 本の動的構造変化に伴う 発光機能のイメージングを目的として, 近年応用物理 学の分野で発展のめざましい近接場光学を応用した近 接場顕微鏡の一種である, 全反射型蛍光顕微鏡 (TIRFM) を製作し ${ }^{2)}$, 新規に合成した $\pi$ 共役系棒状お よびらせんポリマーの 1 分子発光の観測を有機溶媒中 で行った.

TIRFMによる 1 分子蛍光発光イメージングの原理に ついて, 以下に簡単に述べる. 屈折率の高い石英スライ ドガラス $\left(n_{\mathrm{D}}{ }^{20}=1.458\right)$ と屈折率の低い $\left(n_{\mathrm{D}}^{20}=1.407\right)$ テトラヒドロフラン (THF) 溶液の界面に, 臨界角以上 で光を入射させると全反射が起こる. このとき, 界面の THF溶液側の近傍 $100 \mathrm{~nm}$ ほどに閉じこめられた光, 近 接場の一種であるエバネッセント光が発生する. これ を励起光として利用することで, 溶液中においても背 景光を極限まで抑えて, スライドガラス表面に吸着し た $\pi$ 共役ポリマーからの微弱な蛍光を超高感度ビデオ カメラで捉えることができる.つまり,ポリマー1分子 の光機能のイメージングが達成される.

3.1 ポリマー1分子の蛍光イメージング

主鎖中にアントラセン骨格を有する蛍光性ポリマー, ポリ(アリーレンエチニレン) [ポリ(AEPE), 図3a] を 新規に分子設計および合成し, この顕微鏡で夜中観測 したところ, 図3のように, このポリマーからの蛍光に よる輝点がいくつも観測された. 輝点の明るさが異な るおもな原因は, 基板表面への吸着の樣式が異なるた 
(a)
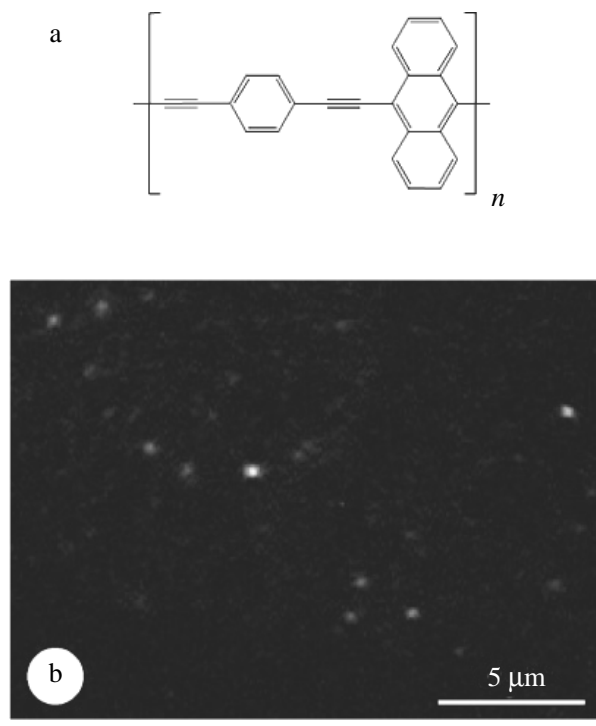

図3 (a) ポリ (AEPE) の化学構造, (b) 全反射型蛍光顕微鏡で 捉えたポリ(AEPE) 1 分子の蛍光発光像 (1nM テトラヒド ロフラン溶液, 室温下)

めと考察している. これら輝点のある一点についての 発光強度の時間変化を追跡したところ, この発光はお よ乥 20 ビデオフレーム $(1$ フレーム $=1 / 30 \mathrm{sec})$ までー 定の強度を保っていたが, 兴の後, 突然背景光のレベル にまで低下した. この結果は, ガラス基板表面から溶媒 中へのポリマー分子の解離過程を見ているものと考察 した.これがポリマー1分子の解離過程でなければ, こ のように 1 段階で発光強度が低下する可能性は低い (もしこれが会合体の解離過程であれば, 発光強度は多 段階で低下すると考えられる).さらに, 良溶媒である テトラヒドロフラン (THF) を溶媒に用いていること, そして溶液濃度が $10^{-9} \mathrm{~mol} / \mathrm{l}$ と希薄であることから, 本 観測条件においてポリマー分子が会合体を形成してい る可能性は低い.さらに, 試料濃度に比例して観測され る輝点数が変化したことと, 輝点の蛍光強度の分布に 試料濃度依存性がなかったことより, ポリマー1分子の 直視が達成されたものと考察した. さらにこの現象は 他の輝点に関しても同樣に生じた ${ }^{3)}$.また別途合成し た,らせん主鎖を有するポリマーについても同樣な結 果を得た 4 .

\section{2 ポリマー1分子の蛍光分光}

図4にポリマーの液中における 1 分子蛍光スペクト ルの時間変化を示した. 6 つのスペクトル [図 4 (1)〜 (6)] は光れ光れ2秒間の積算を行うことで得られたも ので, 大きく以下の 3 つのタイプ $(\mathrm{A}, \mathrm{B}, \mathrm{C})$ に分けるこ とができた.
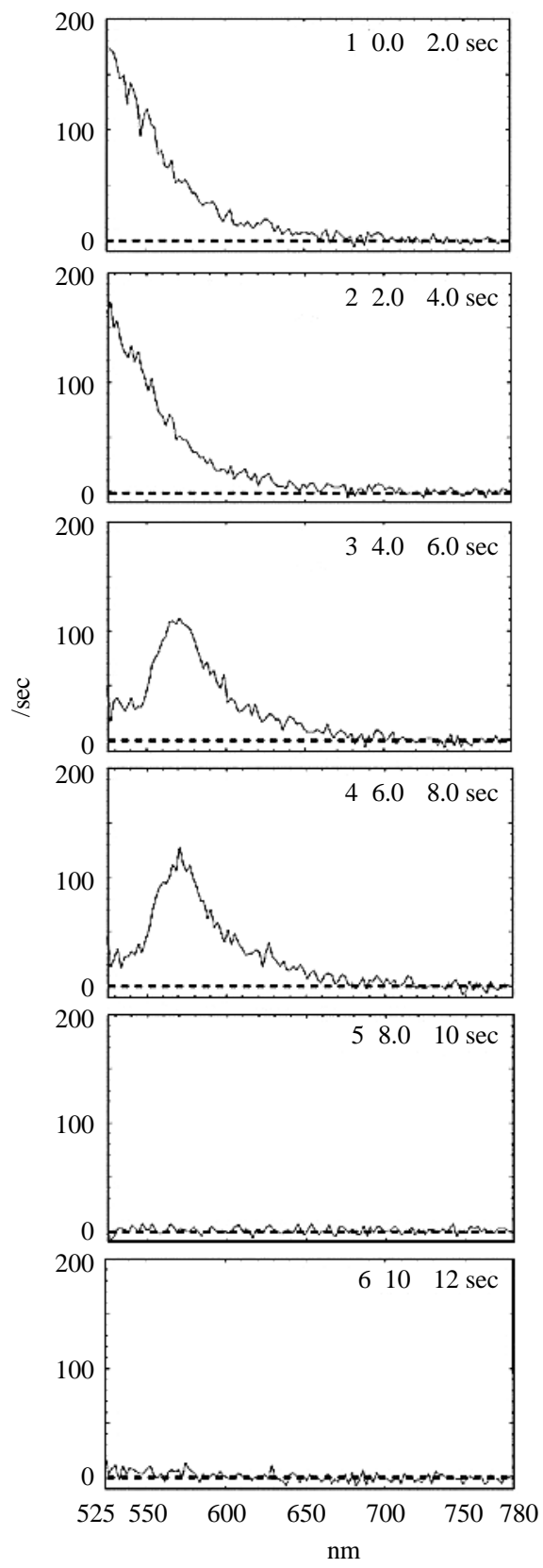

図4 ポリ(AEPE) 1 分子の蛍光スペクトルの動的挙動（室温下 メタノール中, 各スペクトルの積算時間 : 2 秒)

(A) 短波長側から長波長側へしだいに発光強度が低下 している.

(B) 発光波長極大が570 $\mathrm{nm}$ 付近に現れている.

(C) 光強度か完全に背景光レベルにまて低下した.

ここで, (A) はポリマー1分子が基板ガラス表面上 で強く吸着されている状態, ついで (B) は基板上では 
弱く相互作用をしていて, ポリマー1 分子が溶媒中でブ ラウン運動しているのに比較的近い状態, 乥して最後 に (C) はポリマー1 分子が基板上から解離した状態と 考えた. ここで特筆すべきは, 上記のポリマー 1 分子の 発光スペクトル変化か秒のオーダーで生じたという事 実である5

溶液中におけるポリマー 1 分子の発光機能, ならびに その動的変化を実証することができた. このポリマー1 分子からの発光現象は, 溶液中における熱ゆらぎに基 づくミクロブラウン運動を利用したものと考えている. これはまさに生体タンパク質分子が機能を発現させて いる原理である. 将来, この新しい概念に基づく, 溶液中 において単一分子で機能する「単一分子機能材料」と して応用される可能性を示した.

本研究の真の狙いは, 未知の現象の発見に基づく超高 効率光機能材料 - 分子デバイス-の創成と, これを応 用した新しいフォトニクス産業の開拓にある. すなわ ち, 2020 年頃に限界を迎えると予測されている人類の 存亡をかけた最大の課題, エネルギー・環境問題解決 のための, 無尽蔵のクリーンエネルギーである太陽光 を利用したエネルギー変換材料光して太陽光エネルギ 一を駆動源とするデバイスの創出をめざす.

現在, 独立して実施していた上述の研究2.と3. を融
合させ, ポリマー 1 分子の構造と機能の同時観測実験系 の確立を進めている.

\section{謝 辞}

本研究を遂行するにあたり, 共同研究者として多大な る協力を賜りました, 筑波大学物理工学系および東京 大学大学院工学系研究科 重川秀実先生, ならびに東北 大学大学院工学研究科および同学際科学研究センター 樋口秀男先生, およひ科学技術振興事業団 1 分子過程プ ロジェクト 和沢鉄一博士に, この場を借りて, 厚く御礼 を申し上げます。

\section{文 献}

1) Shinohara, K., Yasuda, S., Kato, G., Fujita, M. and Shigekawa, H. (2001) J. Am. Chem. Soc. 123, 3619.

2) Funatsu, T., Harada, Y., Tokunaga, M., Saito, K. and Yanagida, T. (1995) Nature 374, 555.

3) Shinohara, K., Yamaguchi, S. and Higuchi, H. (2000) Polym. J. 32, 977.

4) Shinohara, K., Yamaguchi, S. and Wazawa, T. (2001) Polymer 42, 7915.

5) Shinohara, K., Kato, G., Minami, H. and Higuchi, H. (2001) Polymer 42, 8483. 